\title{
Why do People Refuse Entrepreneurship and How to Improve Entrepre- neurial Education?
}

\author{
Fernando C. Gaspar ${ }^{1, *}$ and Fernando M. Mota ${ }^{2}$ \\ ${ }^{1}$ I. Politécnico de Santarém, Portugal. \\ ${ }^{2}$ Dynamic Network XXI, Portugal.
}

\begin{abstract}
The purpose of this paper is to measure entrepreneurial intentions with a clear timeframe for the intended behavior, thus going beyond a simple measure of attitude. It then looks at those who refuse the idea of becoming entrepreneurs to understand why

This is something the literature on entrepreneurship has ignored so far.

Samples were collected in 2018 from final year university students in Portugal.

Data shows that trusting one's own skills, valuing own job creation, valuing being one's own boss and valuing the independence associated with being an entrepreneur does contribute to student's willingness to become entrepreneurs.

The results provide some important lessons for entrepreneurial education programs, as people who say no to entrepreneurship:

- are less motivated to career factors and more worried about life quality factors;

- see harder obstacles to creating startups;

- trust less in their entrepreneurial skills.

Implications for theory and practice are proposed, as these results can be used to improve entrepreneurial education. This new view on potential entrepreneurs' individual choices is presented as an advancement to the theory and to our present understanding of entrepreneurship.
\end{abstract}

Keywords: Motivations, Abilities, Obstacles, Entrepreneurial Intentions, Non-entrepreneurs, Entrepreneurial Education.

\section{ENTREPRENEURIAL INTENTIONS AND ENTRE- PRENEURSHIP}

Entrepreneurship has become an important driver of employment and economic growth, forcing governments and educational institutions to show an increasing interest in promoting it (Gieure, Benavides-Espinosa, and Roig-Dobón 2019; Shane and Venkataraman 2000; Shane 2004), but for entrepreneurial activity to grow, the increase of entrepreneurial intentions must also happen (Ajzen 1991; Galanakis and Giourka 2017), even though it is not the only factor (Gubik and Bartha 2018). Studying what drives entrepreneurial intentions is therefore fundamental to increasing entrepreneurial activity (Gaspar and Pinho 2007).

At the same time, university policies are progressively moving towards the design of academic entrepreneurship centers, by encouraging their students, researchers and teachers to

\footnotetext{
*Address correspondence to this author at I. Politécnico de Santarém, Portugal; E-mail: fernando.gaspar@esg.ipsantarem.pt
}

turn their findings into patents, spin-offs or technological and business licenses, thereby extending the activities of universities (Wood 2009).

Literature has shown that the inclusion of entrepreneurship courses in academic syllabuses contributes to increase students' intention to create their own business (Hsu, Shinnar, and Powell 2014; Shinnar, Pruett, and Toney 2009; Israr and Saleem 2018). With it, the creation of new businesses becomes as an alternative for students to face the difficulties of finding a career path after the university (Santarelli, Carree, and Verheul 2009).

The purpose of this research is to study antecedents of entrepreneurial intentions among polytechnic students in Portugal.

\section{METHODS AND DATA}

Literature shows four main models that can be used to study entrepreneurial intentions: Shapero's model of the entrepreneurial event (Krueger, Reilly, and Carsrud 2000), Ajzen's 
Fig, (1). Working Model.

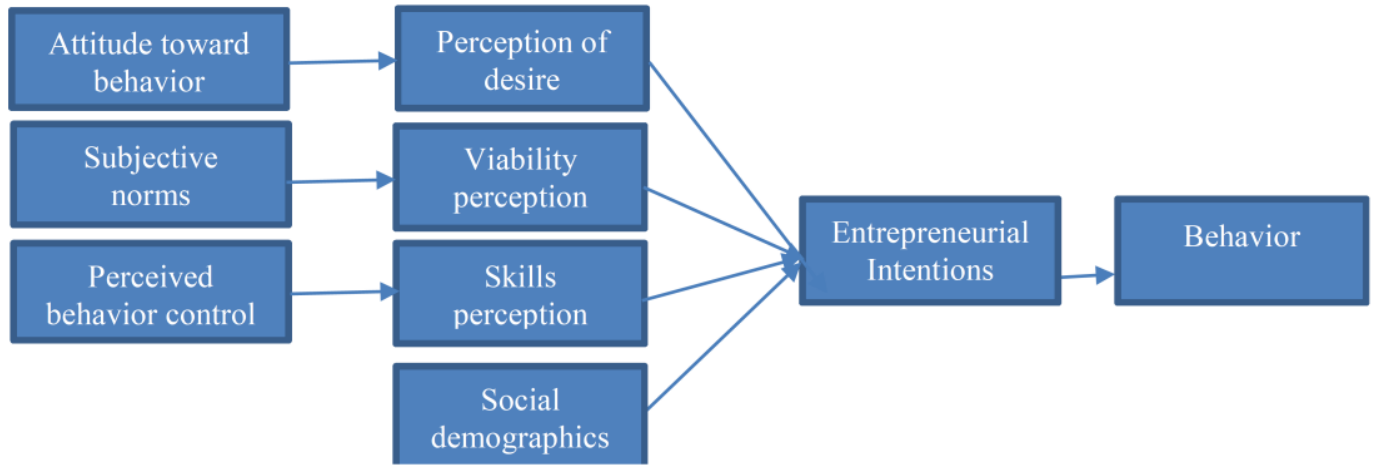

Source: adapted from (Branchet \& Kř́žzová, 2015).

theory of planned behavior (TPB) (Ajzen 1991), Lüthje and Franke's psychological traits model (Gieure, BenavidesEspinosa, and Roig-Dobón 2019; Franke and Lüthje 2004) and the MOA (Motivation, Opportunity, Ability) model (Hui-Chen, Kuen-Hung, and Chen-Yi 2014).

This research will build upon MOA and TBP because of its widespread acceptance among academics and its ability to predict human social behavior.

Psychological traits and personality characteristics were left out for being more controversial as some research using the Big Five model found them not to be determinant of entrepreneurial intentions (Cantner, Goethner, and Silbereisen 2017).

The TPB model stipulates that intentions are predicted by a person's attitudes toward a behavior (ATB), the perceived subjective norms, and the perceived behavioral control (PBC), which can be differentiated into internal and external control attitudes toward a behavior (ATB), the perceived subjective norms, and the perceived behavioral control (PBC), which can be differentiated into internal and external control (Ajzen, 2002a). The core assumption of TPB is that behavioral intentions are an additive function of three conceptually independent factors: attitude toward behavior, subjective norms, and perceived behavior control (Cantner, Goethner, and Silbereisen 2017).

The model we will use in this work assumes the existence of interactions between three explanatory elements (Krueger and Brazeal 1994; Doe 2017; Hui-Chen, Kuen-Hung, and Chen-Yi 2014) that make the MOA model but are actually very close to TPB: 1 ) motivation (defined as the degree to which the person feels an attraction to a particular behavior), something very close to TPB's perception of desire, 2) obstacles, or how the environment supports or poses difficulties to the behavior, something very similar to TPB's subjective norms, 3) self-perceived capacity / perception of personal abilities (defined as the degree to which people consider themselves personally capable of performing this behavior), something very close to TPB's perceived behavior control (Ang and Hong 2000; Sing and De Noble 2003; Entrialgo and Iglesias 2016; Serida Nishimura and Morales Tristan 2011).

This model is also very close to Shapero's, where perceived desirability, perceived feasibility, propensity to act (Krueger,
Reilly, and Carsrud 2000) are replaced by perception of desire (motivations), perception of viability (obstacles), and perception of skills.

Since some of the literature accounts for gender-related differences in entrepreneurial intentions (Branchet and Křížková 2015), social and demographic variables were also included in this research.

The model used in this research is presented in Fig. 1.

After studying the formation of entrepreneurial intentions, this research will then focus on the part of the sample who declared no intention whatsoever of starting a company in the near or far future.

Many studies have been published on entrepreneurship most of them studying successful entrepreneurs. That means most studies look at people who, not only decided to create a startup but also succeeded at that activity.

Most studies do not look at people who created their startups and failed.

Rarely does the literature look at people who decided not to become entrepreneurs.

So, this research looks at people who flat out say, at an early age (university final year students), they do not want to be entrepreneurs. They were asked whether they would like to a) start a company in the short term; b) start a company later in their career; c) never start a company in their entire career.

The last part of this study studies people who answered c). It tries to identify what distinguishes these people from the ones who want to be entrepreneurs and it tries to answer the question: why? Why don't they want to become entrepreneurs? Are they concerned they will not be successful? Do they believe they will not be able to assemble the necessary resources? Are they unable to identify entrepreneurial opportunities? Do they think society does not value the entrepreneur's role?

The answers to these questions will then be used to derive some proposals to upgrade entrepreneurship education.

Samples (Fig. 2) were collected in 2017/2018, with 354 final year students from various polytechnic institutes in Portugal. The instrument used to collect this data was a questionnaire in Portuguese with Likert like 5 point scales, structured in 3 


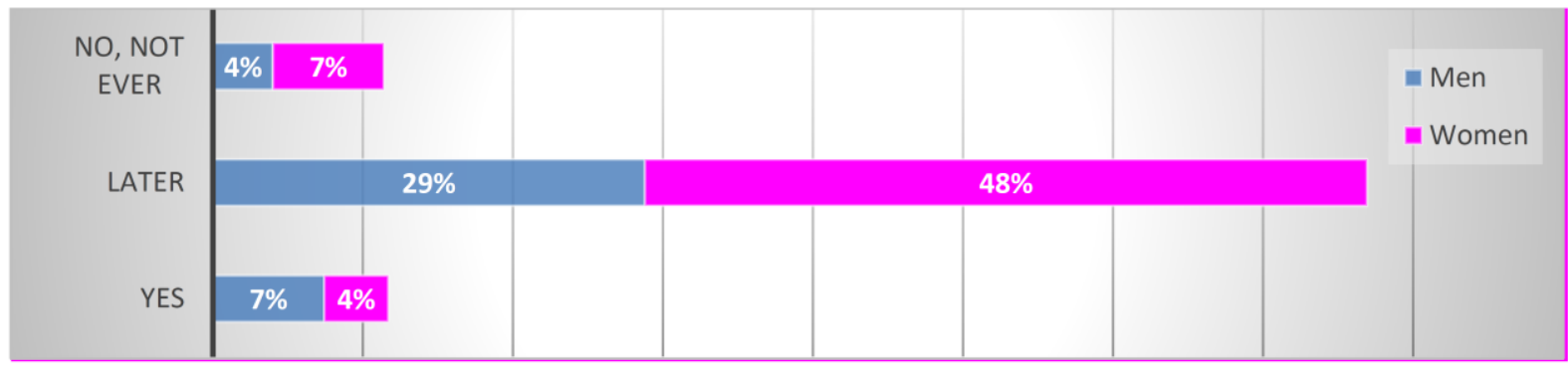

Fig. (1). Samples by gender and entrepreneurial intentions.

parts to evaluate: 1) motivations, 2) perception of obstacles and 3) perception of their own ability to create a startup.

Finally, entrepreneurial intention was measured with a 3 point scale, separating the sample among a) those who declare themselves ready to be an entrepreneur as soon as possible, b) those who choose to undertake that goal later and c) those who declare they will never want to be an entrepreneur.

Data showed high levels of entrepreneurial intentions (either immediate or later intents), much higher than studies done a decade earlier (Pinho and Gaspar 2012).

The model used in this research (Fig. 1) is based on some assumptions that were tested as hypothesis.

Hypothesis 1 - motivations influence positively entrepreneurial intentions;

Hypothesis 2 - perceptions of obstacles influence negatively entrepreneurial intentions;

Hypothesis 3 - perception of own abilities negatively influences entrepreneurial intentions;

Hypothesis 4 - social demographic characteristics (gender, age, job status, international life experience, previous entrepreneurial experience and family entrepreneurial antecedents) of students influence positively entrepreneurial intentions.

These hypotheses were tested using a regression analysis. Potential multi-collinearity problems were them examined by calculating the value inflation factors (VIF's). Moreover, the autocorrelation of residuals was tested (Durbin-Watson test). Finally, the plot of residuals versus predicted values was analyzed to check the assumptions of homoscedasticity and linearity.

Attentions were then turned to the non-entrepreneurs (people who say they will never be entrepreneurs). Even though their numbers lowered considerably from one decade to the second, they may nevertheless hold the secret to improve entrepreneurship education if we can answer the big question: why?

This was done by splitting the sample in two (entrepreneurs and non-entrepreneurs) and comparing them, looking for statistically significant differences, using Levene's F test.

Based on previous research (Pinho and Gaspar 2012) three additional hypothesis were added and tested:

Hypothesis 5 - non-entrepreneurs value obstacles more ;
Hypothesis 6 - non-entrepreneurs have lower perception of their own skills;

Hypothesis 7 - non-entrepreneurs are less driven by professional and own job creation motivations.

\section{RESULTS}

Cronbach's Alpha test was used to analyze the reliability of the constructs and (Table 1) it turned out quite acceptable.

Table 1. Cronbach's Alpha Test.

\begin{tabular}{|c|c|}
\hline \multicolumn{2}{|c|}{ Cronbach's alpha results } \\
\hline obstacles & .792 \\
\hline skill perceptions & .890 \\
\hline motivations & .739 \\
\hline
\end{tabular}

The validity of the scales was then checked, by analyzing content, convergent and discriminant validity.

Content validity was accepted since the scales had already been validated in previously published work (Pinho and Gaspar 2012).

Principal component analysis was performed on the data to validate the scale. Principle Component Analysis requires that the probability associated with Bartlett's test of sphericity be less than the level of significance, something that clearly happened with a value of 0,000 thus confirming the validity of the scale.

Data on motivations, obstacles and skills tells an interesting story. Table $\mathbf{2}$ shows the most cited factors in each group.

Table 2. Motivations, obstacles and skills that stand out.

\begin{tabular}{|c|c|}
\hline Top Ranking & $\mathbf{2 0 1 8}$ \\
\hline \multirow{3}{*}{ Motivations } & Independence \\
& Fulfill dreams \\
& Make money \\
& Create \\
& Job stability \\
\hline Obstacles & Lack of funding \\
& Short personal financial resources \\
& Financial risks \\
\hline
\end{tabular}




\begin{tabular}{|c|c|}
\hline \multirow{2}{*}{ Skills - I can... } & Handle problems \\
& Identify business opportunities \\
& Coordinate tasks \\
\hline
\end{tabular}

Regression analysis was then used to test above listed hypothesis and determine what influences entrepreneurial intentions. The factors constructed for validity testing could have been used in the regression analysis, but they showed lower capacity to explain variance and were for that reason discarded. The summary of these regressions is on Table $\mathbf{3}$ and Table 4.

Table 3. Regression Analysis Summary.

\begin{tabular}{|c|c|c|c|c|c|}
\hline Sample & R2 & F & $\begin{array}{c}\# \\
\text { Relevant } \\
\text { Variables }\end{array}$ & $\begin{array}{c}\text { Durbin- } \\
\text { Watson }\end{array}$ & $\begin{array}{c}\text { Residuals vs } \\
\text { Predictions } \\
\text { Plot }\end{array}$ \\
\hline 2018 &, 543 & 2,108 & 4 & 2,099 & good \\
\hline
\end{tabular}

Having no signs of homoscedasticity and explaining a fair amount of the variation, it was possible to realize that the number of relevant variables explaining this part of the variation in the dependent variable changed. Five variables contributed to student's choice of wanting to be entrepreneurs.

Table 4. Coefficients.

\begin{tabular}{|c|c|c|c|c|c|}
\hline & $\begin{array}{c}\text { Standard } \\
\text { Coefficient }\end{array}$ & & & \multicolumn{2}{|c|}{$\begin{array}{c}\text { Collinearity } \\
\text { Statistics }\end{array}$} \\
\hline variables & Beta & $\mathrm{t}$ & Sig. & Tolerance & VIF \\
\hline Be my own boss & $-0,194$ & - &, 010 & 0,435 & 2,298 \\
\hline
\end{tabular}

\begin{tabular}{|c|c|c|c|c|c|}
\hline I know... Group work & $-0,130$ & $\begin{array}{c}- \\
2,173\end{array}$ & ,031 & 0,680 & 1,471 \\
\hline scientific area of degree & 0,138 & 2,171 & ,031 & 0,601 & 1,665 \\
\hline $\begin{array}{c}\text { I know how... gather re- } \\
\text { sources }\end{array}$ & $-0,127$ & $\begin{array}{c}- \\
2,125\end{array}$ & ,034 & 0,679 & 1,473 \\
\hline Have more free time & 0,149 & 2,034 & ,043 & 0,448 & 2,233 \\
\hline
\end{tabular}

This regression analysis further confirmed that trusting one's own skills contributes to people's willingness to become entrepreneurs, thus partially confirming hyp. 3.

It also contributed to accept that people who value own job creation or being her own boss are more likely to be potential entrepreneurs, thus partially confirming hyp. 1.

Data appears to value more the independence associated with being entrepreneur (free time, be my own boss), also partially confirming hyp. 1.

In the final step of this research, the sample was divided between entrepreneur wannabes and non-entrepreneurs (NEs) and comparisons were then made with a standard set of Levene's F test and student t-test (Table 5).

In this sample NEs attributed less importance to the creation of their own job, but also gave less importance than entrepreneur wannabes to being their own bosses, facing challenges or creating something new, thus confirming hyp. 7. On the contrary, they were more motivated to having more free time and having a fixed schedule.

NEs see obstacles as harder to overcome than do the wannabes, thus confirming hyp. 5 .

Finally, NEs trust in their skills less than wannabes, particularly in some specific entrepreneurial skills (gather resources

Table 5. NEs.

\begin{tabular}{|c|c|c|c|c|c|c|c|c|}
\hline 2018 & & \multicolumn{2}{|c|}{ Levene's Test for Equality of Variances } & \multicolumn{4}{|c|}{ t-test for Equality of Means } & $\begin{array}{c}\text { Equal } \\
\text { Variances }\end{array}$ \\
\hline \multirow{5}{*}{ Motivations } & Be her own boss & 1,54 & 0,215 & $-2,939$ & 349,00 & 0,00 & $-0,364$ & Assumed \\
\hline & Create one's own job & 2,01 & 0,157 & $-3,793$ & 349,00 & 0,00 & $-0,459$ & Assumed \\
\hline & More free time & 6,62 & 0,010 & 2,266 & 53,60 & 0,03 & 0,271 & Not assumed \\
\hline & Facing challenges & 8,33 & 0,004 & $-2,729$ & 49,79 & 0,01 & $-0,263$ & Not assumed \\
\hline & Creating something new & 0,13 & 0,720 & $-2,899$ & 349,00 & 0,00 & $-0,312$ & Assumed \\
\hline \multirow{3}{*}{ Obstacles } & No business ideas & 0,01 & 0,910 & 3,167 & 349,00 & 0,00 & 0,430 & Assumed \\
\hline & Short business know-how & 0,13 & 0,721 & 2,023 & 349,00 & 0,04 & 0,275 & Assumed \\
\hline & Working long hours & 0,17 & 0,678 & 2,550 & 349,00 & 0,01 & 0,342 & Assumed \\
\hline \multirow{2}{*}{ Skills } & I know... gather resources & 17,35 & 0,000 & $-2,062$ & 45,64 & 0,04 & $-0,380$ & Not assumed \\
\hline & I know... develop new product ideas & 14,50 & 0,000 & $-2,307$ & 45,58 & 0,03 & $-0,382$ & Not assumed \\
\hline
\end{tabular}


and develop new product ideas), thus partially confirming hyp. 6.

In short, NEs are less motivated by career factors and more worried about life quality factors than wannabes, NEs see more obstacles to creating startups than wannabes and NEs trust less in their entrepreneurial skills than wannabes.

\section{CONCLUSIONS}

The conclusion must be the significant number of NE, people saying they would never (ever) be entrepreneurs. After all the effort put bi the institutions into improving entrepreneurial education, a significant part of students simply would not consider that career path, even though this numbers were lower than in previous studies (Gaspar 2008; Pinho and Gaspar 2012).

Data showed that motivations and capabilities influenced entrepreneurial intentions (confirming the results of (Hien and Cho 2018)) as did the perceptions of own skills (confirming the results of (Hui-Chen, Kuen-Hung, and Chen-Yi 2014)). Hypothesis 1 and 3 were partially confirmed in both decades, while hypothesis 2 was not supported in this study.

People saying they would never want to be entrepreneurs (NE) were showing less trust in their skills and were seeing obstacles as harder to overcome. These are clear clues for the improvement of entrepreneurial education. Hypothesis 4, 5 and 6 were confirmed in both samples and this represents clear implications for practitioners (entrepreneurial education institutions) and opens new pathways for research on the reasons people exclude themselves from entrepreneurial life.

Further effort must be put in the construction of entrepreneurial education to further increase entrepreneurial intentions, by decomplicating the perception students have about the obstacles to creating a startup, by building their trust in their own skills and by building a better image of the rewards provided by entrepreneurial careers.

Our conclusion is that studying the motivations and perceptions that lead people to choose to become entrepreneurs (or not) advances our understanding of entrepreneurship and should be included in future theory development.

The flagrant difference in motivations between the two samples should be interpreted in the context of cultural changes among the youth, something to be understood with the help of other disciplines.

This shows some of the limitations in this research, to which one should add the geographical limitation of the samples, as well as the exclusion of some areas of undergraduate studies not being taught in polytechnic schools (medicine, law and some other).

\section{CONFLICT OF INTEREST STATEMENT}

The authors declare that they have no conflict of interest.

\section{REFERENCES}

Ajzen, Icek. 1991. "The Theory of Planned Behavior." Organizational Behavior and Human Decision Processes 50: 179-211. https://doi.org/10.1922/CDH_2120VandenBroucke08.
Ang, Swee Hoon, and Don G. P. Hong. 2000. "Entrepreneurial Spirit among East Asian Chinese." Thunderbird International Business Review 42 (3): 285-309.

https://doi.org/10.1002/1520-6874(200005/06)42:3<285::aidtie2>3.0.co;2-5.

Branchet, Bénédicte, and Alena Křížková. 2015. "Gender and Entrepreneurial Intentions in a Transition Economy Context: Case of the Czech Republic." Int. J. Entrepreneurship and Small Business 25 (3): 260-81.

Cantner, Uwe, Maximilian Goethner, and Rainer K. Silbereisen. 2017. "Schumpeter's Entrepreneur - A Rare Case." Journal of Evolutionary Economics 27 (1): 187-214. https://doi.org/10.1007/s00191-016-0467-3.

Doe, Raymond. 2017. "Entrepreneurship among Non-Business Students: Implications for Entrepreneurship Education." American Journal of Management 17 (7): 24-32.

Entrialgo, Montserrat, and Víctor Iglesias. 2016. "The Moderating Role of Entrepreneurship Education on the Antecedents of Entrepreneurial Intention." International Entrepreneurship and Management Journal 12 (4): 1209-32. https://doi.org/10.1007/s11365-016-0389-4.

Franke, Nikolaus, and Christian Lüthje. 2004. "Entrepreneurial Intentions of Business Students - A Benchmarking Study." International Journal of Innovation and Technology Management 1 (3): 269-88. https://doi.org/10.1142/S0219877004000209.

Galanakis, Kostas, and Paraskevi Giourka. 2017. "Entrepreneurial Path: Decoupling the Complexity of Entrepreneurial Process." International Journal of Entrepreneurial Behaviour and Research 23 (2): 317-35. https://doi.org/10.1108/JJEBR-03-2016-0079.

Gaspar, Fernando C., and Luis F. Pinho. 2007. "Environmental Determinants of Firm Creation across Portuguese Regions.” In ISBE 2007 . Institute for Small Business \& Entrepreneurship 30th Edition.

Gaspar, Fernando C. 2008. "Why People Say No To Entrepreneurship? A Comparative Study." In Colóquio Internacional Da ISEOR - Institut de Socio-Economie Des Entreprises et Des Organisations e Da Academy of Management . FR.

Gieure, Clara, Maria del Mar Benavides-Espinosa, and Salvador RoigDobón. 2019. "Entrepreneurial Intentions in an International University Environment." International Journal of Entrepreneurial Behavior \& Research, IJEBR-12-2018-0810. https://doi.org/10.1108/IJEBR-12-2018-0810.

Gubik, Andrea S., and Zoltán Bartha. 2018. "Cultural Characteristics and the Entrepreneurial Intentions of University Students." Journal of Economic Literature 13 (2): 3-12. https://doi.org/10.18096/tmp.2017.02.01.

Hien, Doan Thi Thanh, and Sung Eui Cho. 2018. "The Effect of Software Developers' Capabilities on Entrepreneurial Intention in ICT Industries." International Journal of Entrepreneurship 22 (3): 1-18.

Hsu, Dan K., Rachel S. Shinnar, and Benjamin C. Powell. 2014. "Expectancy Theory and Entrepreneurial Motivation: A Longitudinal Examination Of The Role Of Entrepreneurship Education." Journal of Business \& Entrepreneurship 26 (1): 121-40.

Hui-Chen, Chang, Tsai Kuen-Hung, and Peng Chen-Yi. 2014. "The Entrepreneurial Process: An Integrated Model." International Entrepreneurship and Management Journal 10 (4): 727-45. https://doi.org/10.1007/s11365-014-0305-8.

Israr, Muhammad, and Mazhar Saleem. 2018. "Entrepreneurial Intentions among University Students in Italy." Journal of Global Entrepreneurship Research 8 (1). https://doi.org/10.1186/s40497-018-01075.

Krueger, Norris F., and Deborah V. Brazeal. 1994. "Entrepreneurial Potential \& Potential Entrepreneurs." Entrepreneurship Theory and Practice 18 (3): 91-104.

Krueger, Norris F., Michael D. Reilly, and Alan L. Carsrud. 2000. "Competing Models of Entrepreneurial Intentions." Journal of Business Venturing 15 (5): 411-32. https://doi.org/10.1016/S08839026(98)00033-0.

Pinho, Luís Manuel, and Fernado António Gaspar. 2012. "Intenção Empreendedora Dos Estudantes No Ensino Superior Politécnico Em Portugal.” Jornadas Luso-Espanholas de Gestão Científica.

Santarelli, Enrico, Martin Carree, and Ingrid Verheul. 2009. "Unemployment and Firm Entry and Exit: An Update on a Controversial Relationship." Regional Studies 43 (8): 1061-73. https://doi.org/10.1080/00343400801968361.

Serida Nishimura, Jaime, and Oswaldo Morales Tristan. 2011. "Using the Theory of Planned Behavior to Predict Nascent EntrepreneUrship." Academia, Revista Latinoamericana de Administración 46: 55-71. 
Shane, Scott. 2004. Academic Entrepreneurship: University Spinoffs and Wealth Creation. Cheltenham: Edward Elgar.

Shane, Scott, and S Venkataraman. 2000. "The Promise of Entrepreneurship as a Field of Research." Academy of Management Review 25 (1): 217-26. https://doi.org/10.2307/259271.

Shinnar, Rachel S, Mark Pruett, and Bryan Toney. 2009. "Entrepreneurship Education: Attitudes Across Campus." The Journal of Education for Business 84 (3): 151-59.
https://doi.org/10.3200/JOEB.84.3.151-159.

Sing, G, and A De Noble. 2003. "Views on Self-Employment and Personality: An Exploratory Study." Journal of Developmental Entrepreneurship 8 (3): 265-81.

Wood, M. S. 2009. "Does One Size Fit All? The Multiple Organizational Forms Leading to Successful Academic Entrepreneurship." Entrepreneurship: Theory and Practice 33 (4): 929-47.

Copyright $\odot$ 2020- All Rights Reserved

This is an open-access article. 